\title{
MIRRORING THE CONFLICT SITUATION OF THE OIL-RICH NIGER DELTA REGION OF NIGERIA ON THE SCREEN: A THEMATIC ANALYSIS OF THE FILM - BLACK NOVEMBER
}

\author{
Joseph M. Lucas (a), Fatima D. Vakkai (b), Tordue Simon Targema (c) \\ (a) Taraba State University. Jalingo, Nigeria. Email: josephlucas928[at]gmail.com \\ (b) Taraba State University. Jalingo, Nigeria. Email: timadominic18[at]gmail.com \\ (c) Taraba State University. Jalingo, Nigeria. Email: torduesimon[at]gmail.com
}

\begin{abstract}
This study examines the potentials of film in managing conflict in the oil rich Niger Delta region of Nigeria. This is against the backdrop that since the commencement of oil production in the region in the 1960 s to date, it has continued to experience one form of armed conflict or the other. These manifest in several ways such as kidnapping of foreign oil workers, vandalization of oil facilities and confrontation with security operatives by militants, leaving adverse effects on the Nigerian economy which depends on crude oil as the major source of income. The paradox of plenty or resource curse that has come to characterize the region and how it can be addressed, therefore, is what prompts the current study. Using the Nollywood film- Black November, the study demonstrates that film is an instrument that can be used effectively to manage conflicts in the region. From the viewpoint of Singhal and Rogers' Entertainment-Education approach, the study adopts thematic analysis to identify and discuss the various themes embedded in the film. Findings indicate that several forces are behind the intractable conflict in the region as contained in the film, such as exploitation of resident communities by multinational oil companies, environmental degradation occasioned by oil spillage and gas flaring, and gross injustice, insincerity and human rights abuse by security operatives that make the people lose faith and confidence in both them and the government which they represent. Other causes include betrayal and corruption on the part of community leaders and the burning fire of patriotism in the youth who are determined to fight for their rights. Given the rich thematic embodiment of the film, the study concludes that film has potentials which, if effectively harnessed, will go a long way in managing conflicts in the society.
\end{abstract}

\section{Keywords}

film; conflict management; Niger Delta; Nigeria; Black November; media; visual communication

This work is licensed under a Creative Commons «Attribution» 4.0 International License. 


\title{
ОТРАЖЕНИЕ КОНФЛИКТНОЙ СИТУАЦИИ В БОГАТОМ НЕФТЬЮ РЕГИОНЕ ДЕЛЬТЫ РЕКИ НИГЕР В НИГЕРИИ НА ЭКРАНЕ: ТЕМАТИЧЕСКИЙ АНАЛИЗ ФИЛЬМА "ЧЕРНЫЙ НОЯБРЬ"
}

\author{
Лукас Джозеф М. (a), Ваккай Фатима Д. (b), Таргема Торду Симон (c) \\ (a) Государственный университет Тараба. Джалинго, Нигерия. Email: josephlucas928[at]gmail.com \\ (b) Государственный университет Тараба. Джалинго, Нигерия. Email: timadominic18[at]gmail.com \\ (c) Государственный университет Тараба. Джалинго, Нигерия. Email: torduesimon[at]gmail.com
}

\section{Аннотация}

В исследовании рассматриваются возможности фильма в управлении конфликтами в богатой нефтью дельте реки Нигер в Нигерии. С начала добычи нефти в регионе в 1960-х годах и до настоящего времени в дельте не прекращались те или иные формы вооруженного конфликта. Их причины разнообразны: похищение иностранных нефтяников, вандализация нефтяных объектов и столкновение с боевиками, проводящими операции по обеспечению безопасности. Все это негативно сказывается на экономике Нигерии, зависящей от сырой нефти как основного источника дохода. Этому региону присущ так называемый парадокс изобилия или проклятие богатых ресурсов, и текущее исследование рассматривает меры с помощью которого эту проблему можно было бы разрешить. Объектом исследования является фильм «Черный ноябрь». Исследование показывает, что фильм - это инструмент, который можно эффективно использовать для управления конфликтами в регионе. Используя подход Сингхала и Роджерса «Развлечение-Образование», автор подвергает фильм тематическому анализу для выявления и обсуждения различных, включенных в фильм тем. Результаты исследования указывают на то, что за описанном в фильме неразрешимым конфликтом в регионе стоят несколько сил, таких как эксплуатация местных сообществ многонациональными нефтяными компаниями, ухудшение состояния окружающей среды, вызванное разливом нефти и сжиганием газа, а также грубая несправедливость, неискренность и нарушение прав человека со стороны силовиков, из-за чего люди теряют доверие как к ним, так и к правительству, которое они представляют. Другие причины включают предательство и коррупцию со стороны общественных лидеров и накал патриотизма среди молодежи, полной решимости бороться за свои права. Учитывая богатое тематическое наполнение фильма, автор приходит к выводу, что у фильма есть потенциал, который, если его эффективно использовать, может иметь большое значение для разрешения конфликтов в социуме.

\section{Ключевые слова}

фильм; управление конфликтами; дельта Нигера; Нигерия; «Черный ноябрь»; медиа; визуальная коммуникация

Это произведение доступно по лицензии Creative Commons «Attribution» («Атрибуция») 4.0 Всемирная 


\section{INTRODUCTION}

The spate of violent conflicts that has engulfed present day Nigeria is alarming. Top on the array of such conflicts are the prolonged Niger Delta militancy in the oil-rich Niger Delta region, the Boko Haram insurgency in the North Eastern region, and the myriad of ethnic cum religious conflicts, prominently, the herders/farmers conflicts that have spread through the North Central/North Eastern regions, and increased in intensity over the past few years. Considering the devastating effects of these conflicts on the socio-economic wellbeing of the masses, and the rate at which new forms of violent conflicts erupt in the country on daily basis, it is safe to note that the complexity of the conflict situation in Nigeria is, indeed, deepening by the day. Several factors culminate into these conflicts, principal among which include the struggle for scarce resources such as land, environmental degradation occasioned by exploitation of mineral resources, the struggle for political power, religious intolerance and ethnic chauvinism among an endless array of others (Orounye, 2012; Yuguda \& Goni, 2013; Abdulsalam, 2014). The Niger Delta conflict is particularly unique for several reasons. First, it has one of the longest histories among the various conflicts bedeviling the country now, dating back to the 1960s when the exploration of crude oil began in the region. The conflict passes through several stages of evolution, with each stage assuming a unique posture, but maintaining the same goal, which is, demanding for a fair share of the resources tapped from the region, and reduction in, or fair compensation to the damage which the activities of oil exploitation cause to the region and its environment.

Second, it is a conflict which the major perpetrators clearly itemize their demands, (which are not only legitimate, but also genuine), and utilize appropriate channels of communication to make the demands known to all concerned stakeholders. This effort has attracted a lot of international agencies to look into the conflict and explore strategies to mitigate it, and has also compelled the various administrations that have ruled the country over the years to come up with measures towards finding lasting solutions to the conflict, such as the establishment of the Niger Delta Development Commission (NNDC) by former President Olusegun Obasanjo in the year 2000 (Nwankwo, 2015). The intensive deployment of the media of communication to complement the efforts towards pressing home, the demands and concerns of the region, and projecting to the whole word, the realities in the region that have continued to nurture and sustain the conflict over the years, is what ignites the current study. 
Jeta Amata in his film - Black November vividly presents the complexity of the conflict situation in the region. His film can be best described as an attempt to bring unto the screen, the multifaceted nature of the causes of constant conflicts and unrest in the region. From Gallo's complexity and systems approach to conflict analysis (Gallo, 2012), it is glaring that the film $x$-rays some of the factors that make the conflict situation in the region a very complex one. This complexity as portrayed in the film stems from the fact that many institutions in the society are culpable for the continued occurrence of the conflict. It is against this backdrop that this study interrogates the strategic role of film as interventionist medium in managing conflict in the region, by exploring the thematic embodiment of the film with the aim to demonstrate how well film can help to articulate the right messages that would lead to desired solution(s) to societal problems that always result in violent conflicts.

\section{NIGER DELTA CONFLICT: A HISTORICAL PERSPECTIVE ON THE CAUSES, MANIFESTATION AND CONSEQUENCES}

The Niger Delta question has been interrogated at several forums, both at academic gatherings, and at national and international levels. As a result, a corpus of literature exists, that documents the causes, nature, manifestations, consequences and mitigation strategies of the conflict that preoccupies the region over the years. The area which is described as the Niger Delta region of Nigeria lies between latitudes 40 and 6o north of the Equator and 4o and 8o east of the Greenwich. It comprises nine out of the thirty-six states that make up the Federal Republic of Nigeria. These are: Akwa Ibom, Cross River, Edo, Imo, Rivers, Bayelsa, Delta, Abia and Ondo, making it coterminous with all of Nigeria's oil producing states (Afinotan \& Ojakorotu 2009). (Nwankwo, 2015, p. 383) notes that the history of conflict in the Niger Delta region dates back to 'the Akassa Raid of 1895, when the inhabitants of the area resisted economic domination by British merchants... the consequences of which included the British invalidation and overthrow of the Royal Niger Company (RNC) and later colonialism'. The discovery of crude oil deposit in the region in the 1950s, and subsequent exploration and exploitation of the resources resulted in quite a number of issues which have continued to sustain the renewed spirit of violent conflicts that have come to characterize the region over the years (ibid).

Among the numerous causes of conflict in the region, (Nwankwo, 2015) highlights two leading causes, namely: the struggle for control over resources and the issue of environmental degradation occasioned by the 
activities of multinational oil companies. The question of who will control the oil resources in the region has been a contentious one ever since the exploitation of oil in the region began. (Nwankwo, 2015) notes that, prior to oil exploitation in the country; agriculture was the mainstay of the economy. During this period, derivation formula was pegged at $50 \%$, the implication of which was that the individual regions were entitled to $50 \%$ of the income they generated. This has been reversed with the discovery of crude oil, where derivation formula dropped to $1.5 \%$ then grew to $3 \%$ and currently, it is at $13 \%$. The change was based on the government's argument that oil is an accident of geographical location, an arrangement that does not augur well with the Niger Delta region which has crude oil deposit in abundance. Revenue allocation, thus, has become the major point of contestation and agitation in the region. The second major cause of conflicts in the region is the issue of environmental degradation. Citing Uwadiae, (Nwankwo, 2015) maintains that:

The region has been faced with the problems of oil spillages and gas flaring, which have caused serious atmospheric pollution, ground water and soil contamination, constant heat around the flare pits and abnormal salinity of the pool water, resulting in serious health hazards for the local inhabitants, and of course, grave disturbance to the life cycles of plants and animals in the region (p. 383).

Accordingly, (Afinotan \& Ojakorotu, 2009) enumerates other causes of conflict in the region to include rising level of poverty, political subjugation and internal colonization, and failed expectations on the part of people of the region, who feel that the nation relies on resources from their region for sustenance, but leaves them impoverished and deprived. Agitations by militant groups in the region, thus, are premised on this reality, and the demand for social amenities and infrastructural development in the region to make life easy for inhabitants has dominated the agenda of the various militia groups that have emerged in the region. The perception of the people within the host communities of the Niger Delta is that, rather than achieve development, oil production in the region has bedeviled the communities with environmental degradation, mass poverty and oppression, coupled with cases of human rights violations by government security agents in the region (Nwankwo, 2015).

It is in pursuit of economic empowerment and emancipation of the region that Isaac Adaka Boro in 1966 led a revolution that resulted in the formation of the Niger Delta Republic. The leaders of the failed republic had intended to put pressure on the federal government through civil disobedience to redress the economic imbalance created through oil exploration/exploitation in the region, thereby making it difficult for the people 
to engage in farming and fishing, which are mainly the vocations of the people of the region. The protest, though unsuccessful, created the basis for the continuing agitation among concerned groups that are fighting for the liberation of the Niger Delta people. Long after Boro's agitation, the situation in the region remains unaddressed as expected, a reality that prompted the renowned environmental activist, Ken Sarowiwa to embark on another peaceful struggle for the emancipation of the Ogoni People from state-imposed poverty in the 1990s (Afinotan \& Ojakorotu, 2009; Nwankwo 2015).

Today, the struggle in the region has come a long way, and has given rise to so many protest groups fighting for economic liberation, many which have come and gone, with some still in existence. These, according to (Afinotan \& Ojakorotu 2009), and (Nwankwo, 2015) include the Movement for the Emancipation of the Niger Delta (MEND), the Niger Delta Peoples Volunteer Force (NDPVF), the Joint Revolutionary Council (JRC), and Movement for the Survival of the Ijaw Ethnic Nationality (MOSEIN). Others include the Pan-Niger Delta Resistance Movement, the Environmental Rights Action (ERA), the Ijaw Youth Council (IYC); the Movement for the Survival of the Ogoni People (MOSOP), and the Movement for Reparation to Ogbia (MORETO). Accordingly, the mode of operation of these groups varies, and ranges from peaceful protests, media warfare and appeal, and in extreme cases, physical violence such as vandalization of oil facilities, kidnapping of oil workers (mostly Europeans) and confrontations with security officers. Another worrying dimension to the manifestation of these conflicts is the emergence of ethnic nationalism, which has helped to deepen the complexity of the Niger delta problematic, as (Nwankwo, 2015) notes, that:

Ethnic nationalism in the Niger-Delta has become one of the major problems in the region, as many people under the disguise of fighting for the economic emancipation of the Niger-Delta people exploit the oil companies and federal government by demanding money that never gets to the hands of the downtrodden citizens in the Niger-Delta region (p. 384).

Consequently, the effects of the constant squabbles between militant groups in the region and oil companies/security agencies are multifaceted, with serious impact on the country's GDP. 


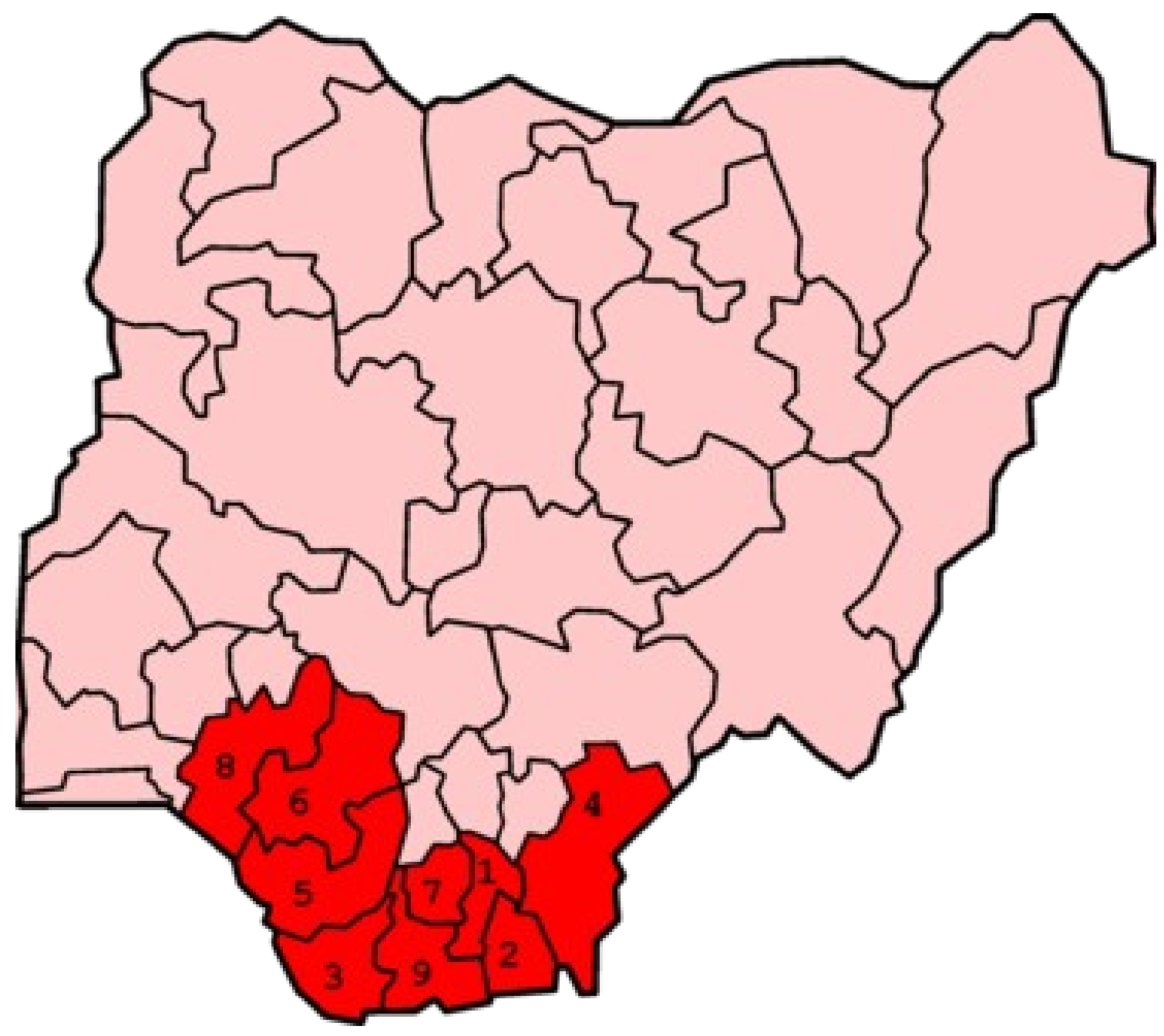

1. Abia

2. Akwa Ibom

3. Bayelsa
4. Cross River
5. Delta
6. Edo

7. Imo

8. Ondo

Fig.1. Map of Nigeria showing the nine states that make up the Niger Delta region

Governments over the years have come up with strategies to minimize the occurrence of violent conflicts in the region, such as the establishment of the Niger Delta Development Board (NNDB) in 1960, the Oil Mineral Producing Areas Development Commission (OMPADEC) in 1992, the Petroleum (Special) Trust Fund (PTF) in 1995, the Niger Delta Development Commission (NDDC) in 2000, and the establishment of the Ministry of Niger Delta Affairs in 2008 (Okolie-Osemene, as cited in Nwankwo 2015). These agencies are saddled with the responsibility of cushioning the effects of oil production activities on the environment and its residents. 
Several development projects have been executed in this regard, courtesy of these agencies. Also, in attempt to reduce the plights of people in the region, the various multinational oil companies operating in the region evolve corporate social responsibility measures which address multifaceted issues ranging from granting of scholarships to residents of the region, provision of social amenities such as roads, blocks of classrooms and safe drinking water. These measures exist side-by-side with their numerous shortcomings, and are often times, accused of been exploitative in nature. The security Joint Task Force that are always drafted and sent to the region to quell riots are not spared of misdoings either, and are accused of several ills such as human rights abuse, raping and extrajudicial killings of citizens among others. These, coupled with internal domination by elites in the region, have deepened the complexity of the conflict situation in the region, and made it to remain intractable and unresolved despite the measures put in place to tame it (Afinotan \& Ojakorotu, 2009; Nwankwo, 2015).

\section{CONCEPTUAL ISSUES: FILM AND CONFLICT MANAGEMENT}

A lay man's understanding of film is as simple as film being a flexible strip of plastic, or other material coated with light sensitive emulsion for exposure in a camera, used to produce photographs or motion pictures. This perception conceives of film as merely a story or event recorded by a camera as a set of moving images and shown in a cinema or on television. A dipper layer of meaning, however, can be inferred from the word. (Nwabueze, 2014) defines film as motion picture production for audience entertainment or information dissemination. It could be in form of movies involving interesting plots for audience entertainment, or documentary films aimed at enlightening the audience on specific themes, subjects or issues. Quite often, the terms- film, movie and motion picture are used interchangeably, but the main idea that runs through them is that they contain a series of still photographs, projected in rapid succession onto a screen by means of light.

Film in recent times has become an art, studied because of its unique potential of packaging and projecting reality to society (Owens-Ibie \& Ademosu, 2017; Suntai \& Targema, 2017; Chile \& Targema, 2017). (Jacobs, n.d., p. 1) succinctly captures this description of movies in the following words: 'Movies are entertainment. Movies are documents of their time and place. Movies are artistic forms of self-expression. Movies we see at theatres, on television or home video are typically narrative films. They 
tell stories about characters going through experiences... From this assertion, it could be deduced that films are forms of entertainment media that package and present to the society, the realities of human existence, where the various characters act out the issue at stake for the audience.

Citing McLuhan, (Kurfi, 2017) notes that, the movie is not only a supreme expression of mechanism, but paradoxically, it offers as a product, the most magical of consumer commodities, namely: dreams. It is, therefore, not accidental that the movie has excelled as a medium that offers poor people roles of riches and power beyond the dreams of avarice. Empirical researches have established that film has potentials which if well harnessed, can go a long way in effectively managing conflicts in society (see Kurfi, 2017). (Nykon, 2011) argues for the deployment of film towards amicable resolution of conflict in the society. According to him:

Nurturing a belief in universal humanity and the efficacy of peaceful alternatives to violence can be achieved by modeling such behaviors, beliefs and attitudes in mainstream film. The resulting films would be 'humanizing' as opposed to 'dehumanizing' and thus constitute a positive contribution to society (p. 18).

Conflict appears to be one of the most studied concepts in the humanities and social sciences. This is because it occupies a central stage in the process of human existence, and has continued to redefine relationships between people and communities. Although proliferation of definitions abound for the concept, this study subscribes to the definition of (Anstey, 2008), who states that: conflict exists in a relationship when parties believe their aspirations cannot be achieved at the same time, or perceive a divergence in their values, needs or interests (latent) and purposefully mobilize the power that is available to them in an effort to eliminate, neutralize, or change each other to protect or further their interests in the interaction (manifest conflict). Conflict, thus, is a situation of intense disagreement (that could, or could not result in physical violence) over resources or ends shared by two parties (emphasis, original).

Conflict management is the process of handling conflicts in the society in such a way that will minimize frequent occurrence of violent conflicts, and pave the way for amicable resolution of latent conflicts that exist among people. (Jeong, 2010) presents four major approaches for effective conflict management and resolution, these are: negotiation, mediation, facilitation and reconciliation.

Negotiation - is a process of bargaining to attain mutual ground among two conflicting parties in a conflict, where both parties shift grounds and arrive at a 
common ground, thereby, paving the way for amicable resolutions. It entails 'trading of concessions and invention of options for mutual gain', where the interests of each party are sought and 'commonly agreeable solutions' are explored (Jeong, 2010, p. 153)

Mediation - involves a third party in the process of conflict resolution. It is the coming in of a third (and of course, neutral) party to help the conflicting parties negotiate and amicably resolve their differences.

Facilitation - enhancing mutual understanding of parties in a dispute, where group discussion or interaction is designed for a collective search for problem solving based on mutual understanding of the issues and sources of problems

Reconciliation - the immediate post-conflict activity which deals with mending relationships that have been spoiled as a result of the conflict, it is the process of re-uniting the conflicting parties to embrace themselves once again and forge ahead as one (see also, Egbefo, Mohammed, Apara \& Ngarka, 2010).

Apparently, all these processes of conflict management and resolution rely on the mass media for success, and what makes film particularly important in the process is its ability to create and resolve conflicts. At the end of every film, viewers acquire skill on how to engage in the various processes of conflict management. (Kurfi, 2017, p. 335) agrees with this position, when he summits that: 'film and conflict are interrelated. Perhaps, this is why one hardly sees a film without conflict as one of its elements. Film deliberately creates and resolves conflict basically to educate viewers on how to handle conflict related issues.' This potential of film makes it a vibrant tool in the process of conflict management and resolution, as we would discuss in depth in the subsequent sections.

\section{THEORETICAL FRAMEWORK}

This study is hinged on the Entertainment-Education approach. Also referred to as the E-E approach to behavior change communication, Entertainment-Education approach is a brainchild of Arvind Singhal and the eminent scholar, Everett Rogers (1999). In the simplest of terms, Entertainment-Education is an approach in which social messages are incorporated into entertainment programs. According to (Singhal \& Rogers, 1999):

Entertainment-education is the process of purposely designing and implementing a media message to both entertain and educate, in order to increase audience members' knowledge about an educational issue, create favorable attitudes, and change overt behavior. Entertainment- Education seeks to capitalize on the appeal of popular media to show individuals how they can live safer, healthier, and happier lives (p. 12). 
Entertainment Education is a deliberate attempt to weave education and morality into entertainment oriented media content with a view to enhancing positive attitudinal change. According to (Littlejohn \& Foss, 2009 , p. 342), 'thoughtful, deliberate, and purposeful embedding of educational messages in entertainment genres, in all their nuance and complexity, is central to the entertainment education strategy'. Entertainment Education is a media strategy that enables the producer to use one stone and kill two birds- entertainment and education at the same time (Suntai \& Targema, 2017). Entertainment-Education comes in many forms including serial drama, broadcast on television and radio, cartoons, interactive talk shows and folk media. Elaborating further, a report by Johns Hopkins Bloomberg School of Public Health (cited in Suntai \& Targema, 2017) lists public service announcements, situation comedy, feature films, reality programming, magazine or variety programs, theatre and street theatre, forum or interactive theatre, animated cartoons, comic books or graphic novels and photonovelas, internet and mobile phone programming as some of the media where Entertainment Education find expression.

Entertainment-Education has been widely applied in health communication and agricultural extension programs, where research evidence indicates positive results. Notable examples include the Soul City television and radio program in South Africa which was initiated in 1994, and has, over the years, been the leading program in educating the people on HIV/ AIDS and other related health diseases (McPhail, 2009; Tufte, 2002). The Tanzanian Soap Opera- Twende na Wakati (Let's Go with the Times) was also established in 1993 to serve two main purposes- to inform the population about the different ways to deal with the AIDS problem, and also to inform the public about family planning techniques (McPhail, 2009). This program was modeled on the Entertainment-Education approach, and was quite instrumental in achieving the desired attitudinal change. Other programs on the media that are aimed at achieving attitudinal change such as BBC's The Archers, Canadian Broadcasting Corporation's Farm Radio Forum, among several others adopt the Entertainment-Education approach, and have recorded varying degrees of success.

Similarly, several academic researches have been anchored on the principles of Entertainment-Education approach. (Katu-Ogundimu, 2013) who reviews a Nigerian Nollywood film- Jenifa, finds it worthy and educating using the Entertainment-Education lenses. The study identifies and discusses three major themes- crisis of social class identity, women as victims of societal vices and 'sexploitation' of women by women. These have been discussed as depicted in the movie vis-à-vis contemporary realities, 
given that they are among the major issues that bug society, particularly, the female gender. (Suntai \& Targema, 2017) also adopt the Entertainment-Education approach to explore the thematic embodiment of the computer-animated film- Madagascar Escape 2 Africa. The study finds the film worthy in terms of thematic endowment, with relevant themes to the personality development of children such as the relevance of every talent/ skill, the power of unity, love, innovation and adventure. Thus, given its relevance in both theoretical and practical applications, EntertainmentEducation approach is a suitable framework to anchor discussion in the current study.

\section{METHOD}

This study adopts qualitative content analytical approach to explore and discuss in depth, the various themes embedded in the film under review. Qualitative content analytical approach as used in the study is a thematic analysis that enables the researchers to engage intimately with the communication material in order to unravel the various themes contained therein. Using this method, therefore, the major ideas in the film are grouped into themes and discussed, vis-à-vis the conflict situation and realities of the Niger Delta region.

\section{THE FILM - BLACK NOVEMBER}

Black November presents a struggle by activists in the Niger Delta region to emancipate the people of the region from the untold hardships that arise from oil exploitation in the region. Gas flaring and oil spillage cause serious damage to lives, property and the environment, making life difficult for the people. In an attempt to put an end to this hardship, Ebiere, a beneficiary of Western Oil Company Scholarship lends voice to her people, gaining their monumental support. The spirit of patriotism, though shared by all, is, however, perceived differently from the viewpoints of those involved in the liberation movement. For instance, while Ebiere believes strongly in non-violence and peaceful protest, Dede, (her fiancé) and his fellow youths believe in violence, as according to them, '... the only language the West understands is violence...' This disparity in ideology complicates the struggle for liberation in the region, thus, setting the tune for the movie.

Attempts by Ebiere to actualize her vision of peaceful protests on several occasions end in dead lucks, compounded by non-cooperative security agencies that see protests and mass mobilization of citizens as attempts to overthrow the military government, and as a result, do all they 
can to clampdown on the masses and frustrate civil protests. Worst still, community leaders collaborate with the Western Oil Company to exploit the masses, as cases of gas flaring and oil spillage are on the rise, forcing Dede and his fellow compatriots to explore the option of violence. Quickly mobilizing themselves to the creeks under the umbrella of the United Peoples Front for the Emancipation of the Niger Delta People of Nigeria, they commence kidnapping of foreigners working in oil companies, vandalization of oil facilities and hostilities towards the Western Oil Company.

The Western Oil Company's move to use Ebiere and achieve meaningful dialogue with the militants results in the eventual death of Dede, the leader of the movement, alongside several other militants and security personnel, thus, worsening the conflict situation. Security operatives did not help matters either, as cases of human right abuses such as bullying and molestation of residents, harassment and rapping of women in the region are on the increase. Meanwhile, nemesis catches up with the four community leaders who share money received from the Western Oil Company among themselves, as one of them confesses, renounces the act and opts to return the money, given the rising degree of injustice and violence in the land. Threatened by this development, the trio conspires against him and poisons him to death.

A mob action by residents ends up in jungle justice for the three chiefs who are locked inside a car, and set ablaze. Ebiere who understands the mischief that government is up to, offers herself as a sacrificial lamb to save the rest of the community members, who indeed, spearhead the murder, from mass execution. Tamuno, Dede's cousin who resigns from the Nigerian Police Force because of its insincerity in handling the conflict situation in the region and joins the United Peoples Front for the Emancipation of the Niger Delta People of Nigeria, sets to set Ebiere free. He quickly mobilizes his gang to the U.S., and holds hostage, Tom Hudson, the chairman, Western Oil Company in Nigeria to bargain for Ebiere's release. Intelligence tactics from the U.S. anti-terrorism and security agencies, however, prevail, and Ebiere hangs on a noose in the premises of Warri prison, thereby, paying the ultimate price for her dear land.

\section{EMERGING THEMES AND DISCUSSION}

Black November is endowed with themes that are reflective of the realities in the Niger Delta region. This section identifies and discusses some of the themes under three broad categories, viz: the causes of militancy, 
armed struggle and restiveness in the Niger Delta region, the spirit of patriotism and the quest to fight for the rights of the masses, and mobilization for peaceful, non-violent struggle with its concomitant multifaceted challenges. Collectively, these themes have articulated the agenda for a nonviolent movement in the conflict-ridden region towards achieving a lasting solution to the myriad of problems bedeviling it.

\section{MAJOR CAUSES OF MILITANCY AND ARMED STRUGGLE IN THE NIGER DELTA REGION}

The major causes of constant struggles and militancy in the Niger Delta region as portrayed in the film are:

\section{Environmental degradation, occasioned by oil spillage and gas flaring}

The film demonstrates this issue as one of the major causes of conflict in the region. Prior to the discovery of crude oil in the region, farming and fishing were the major occupations of inhabitants (Apuke, 2017). However, with the commencement of oil exploitation in the region, constant oil spillage from pipelines leaves the land infertile, with damaging effects on the rivers and their resources. To this end, oil exploitation has deprived inhabitants of the region of their traditional occupations, with no alternative to rely on. Tamuno articulates this message as the reason why the gang embarks on the armed struggle, thus: 'my people are dying, our lands are devastated, our farmlands, livestock, wildlife...' Similarly, in an exchange of words with security operatives at the scene of a licking pipeline, one of the women leaders query: 'so what would you rather we do? Stand by and watch the property of the federal government of Nigeria spill and spoil our land?' Indeed, all through the film, the damaging effects of oil exploitation is constantly portrayed, so that the audience will get to understand the extent of environmental degradation in the region, occasioned by oil production. Plates 1 and 2 below are screenshots of environmental effects of oil production activities in the region. 

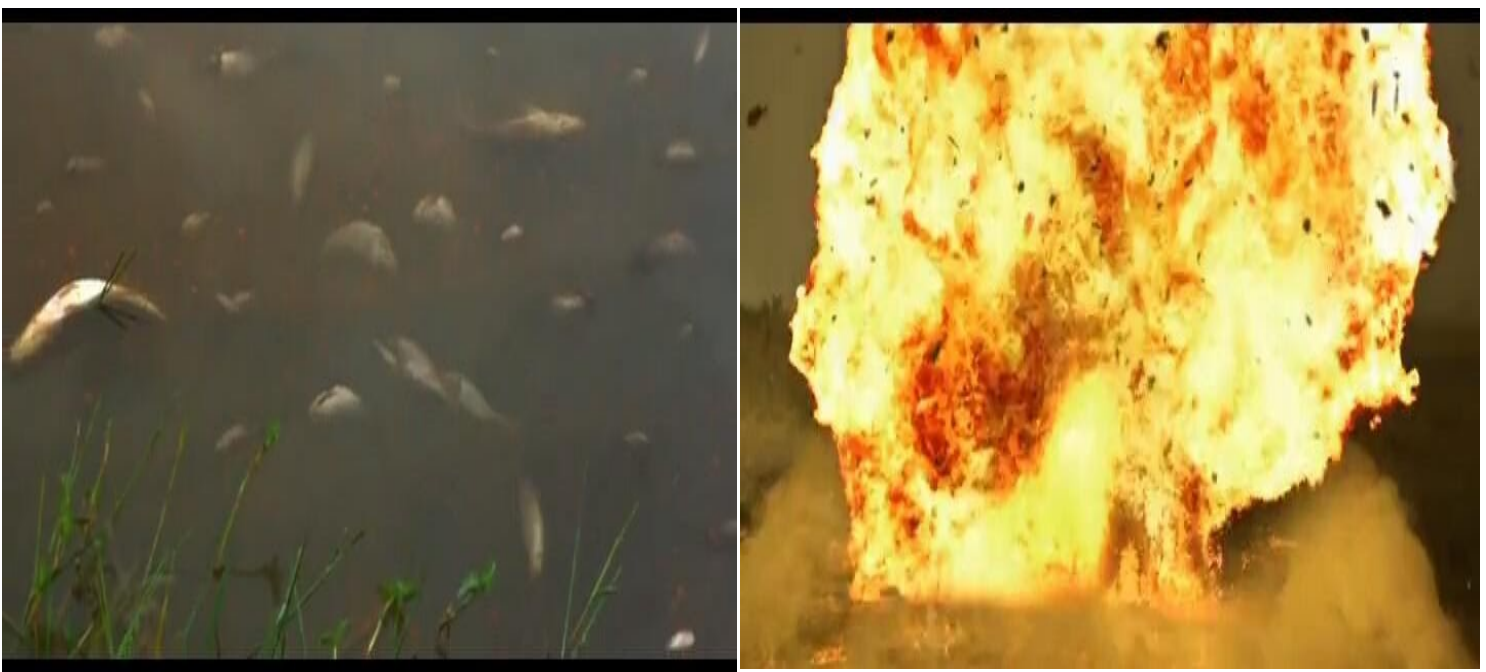

Plates 1\&2: Screenshots of dead fish as a result of oil spillage, and pipeline blast in the film

\section{Exploitation of the masses by oil companies}

This is also among the major causes of conflict in the Niger Delta region. This becomes rather complicated as local elites join the oil companies to extend the frontiers of the exploitation, as (Galtung, 1971) postulates in his theory of structural imperialism. Black November depicts this reality extensively; in fact, it is one of the most occurring messages echoed in the film. For instance, after a clash with security operatives at the scene of a licking pipeline that leaves scores of residents killed, the Western Oil Company offers to compensate the people. However, the delegation drafted from the company only succeeds in pitching one family against the other, resulting in a chaotic gathering. It is at this point that Ebiere assumes her role as the mouthpiece of the masses; her opinion carries the day, when she addresses the gathering as follows:

Good show, good show you put up here, another wonderful way of pitching family against family, or would I say man against man, you come here, enriching yourselves from the spoils of our land, in the process, wiping out families and generations. Yet you keep the foul burning, keep the people unrest, and they would rely on you. What they do is give us sickness, and then treat us, they make us hungry, and then feed us, they kill our loved ones, and then offer us money for burial. Can you not see their plan? It is high time you start to think more of the people, other than your selfish fat pockets... if you do not change your ways, the people will rise.

This, no doubt, sparks the revolutionary fire of Dede and his fellow compatriots in the struggle, culminating into the United Peoples Front for the Emancipation of the Niger Delta People of Nigeria. While holding 
Tom Hudson hostage in the U.S., the terrorists, led by Tamuno articulate their basis for agitation as follows: ' $50 \%$ of our oil comes to the United States' 'one, out of every five Americans uses Nigerian oil' 'we export crude oil to you people, only to import refined oil, why? Because Western Oil and our corrupt government won't allow our refineries to work.'

This revolutionary spirit is ignited by the exploitative mode of operation of Western Oil, which has co-opts few indigenes of the Niger Delta to help exploit the people to the fullest. Efforts by Western Oil to woo Ebiere to its side, however, prove abortive, as she chooses to speak for her people. This exploitative disposition of multinational companies has been criticized for perpetuating underdevelopment in Third World nations. (Stiglitz, 2006) notes that they hold the economies of such smaller nations to ransom, and help to actualize the 'paradox of plenty', or what is also referred to as resource curse for many developing nations with rich mineral deposits.

\section{Betrayal and corruption: the failure of community leaders and stakeholders}

Another worrying dimension to the conflict in the Niger Delta region is the role of dubious community leaders. Often times, they are used as the whip with which oil companies chastise residents. (Nwankwo, 2015) decries this unfortunate trend when he notes, that:

Ethnic nationalism in the Niger-Delta has become one of the major problems in the region, as many people under the disguise of fighting for the economic emancipation of the Niger-Delta people exploit the oil companies and federal government by demanding money that never gets to the hands of the downtrodden citizens ... (p. 384).

The four community leaders who represent their people in a dialogue with Western Oil in Abuja after a blast of a pipeline demonstrate this reality. They share the $500 \$$ offered by the oil company among themselves, and devote just a small fraction to the victims. Corruption is so pervasive in dealings of the oil company with resident communities to the extent that the CEO, Tom Hudson, would tease: ' what Nigerian does not accept a bribe?' As one would rightly expect, several attempts are made to woo Ebiere to the side of the Western Oil company given her increasing popularity among the people, but to no avail.

A mediator between Western Oil and host communities insists: 'this is Nigeria Ebiere, think like a Nigerian...this is not a bribe, it is just the company's way of saying 'we appreciate your efforts...'. Ebiere's response to him is rather demeaning and embarrassing: 'I really do appreciate this, but 
I must decline your offer. If I had wanted a lucrative job, I would have stayed back in the U.S. My desire to be here is for the people.' Thus, she distinguishes herself as an activist who has her people at heart, and spearheads their course.

To the credit of the film, the corrupt leaders have paid for their betrayal. The saga leaks in the long run and the angry residents dispense jungle justice on them. This is sure a lesson to all who have the mandate to represent their communities in different capacities. At the end of the film, the viewer sees the extent to which community leaders who are supposed to speak for their people are complacent, and turns to be agents of oppression in the hands of the oil companies, thus deepening the complexity of the conflict.

\section{Injustice, lack of sincerity and human rights abuse by security agencies}

Empirical evidence documents the gross human right abuse perpetrated by security agencies in the Niger Delta region. Black November depicts this reality in details, as the film is replete with scenes that show security operatives molesting, humiliating and dehumanizing innocent civilians. No doubt, security operatives have contributed a lot to the deteriorating security situation in the region according to the film. Their zerotolerance posture to peaceful protest translates into armed struggle, kidnapping and valdalization of oil facilities by the youth. It is pathetic to watch officers of the Nigerian army brutalize innocent vulnerable women protesting at the premises of Western Oil Company. At a particular scene in the movie, an officer of the Nigerian Police Force lit fire at a licking pipeline, killing scores of residents. Husbands watch in complete shock as officers of the Nigerian Army rape their wives in broad daylight.

These acts of injustice coming from security operatives diminish the confidence of the masses in them, and ignite violent struggle and restiveness among the youth in the region. Since security operatives represent the state, residents have lost faith in the government as well, and the 'patriotic' youth are prepared, with their minds hardened after several experiences of betrayal, molestation and killing by security operatives, to go extra mile, fighting for their rights. Plates 3 and 4 below are screenshots of human right abuses by security operatives in the film. 


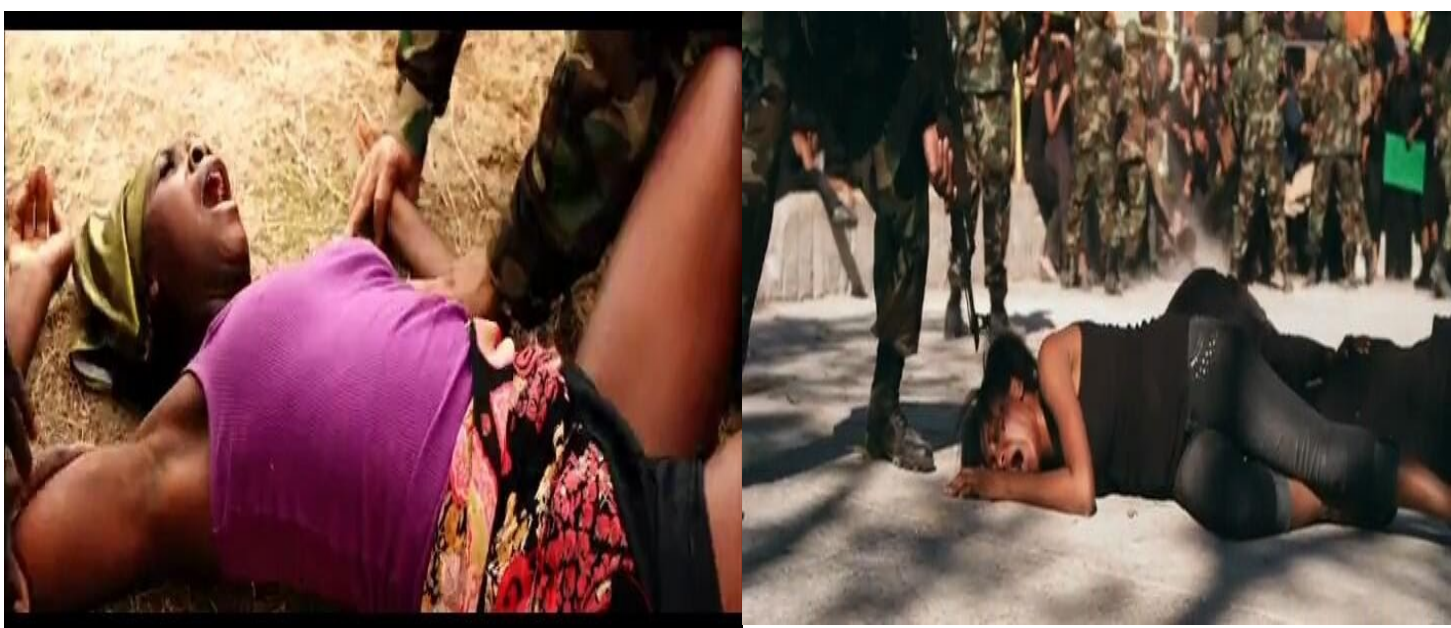

Plates 3\&4: Screenshots of military officers rapping a woman in the presence of her husband, and military officers bullying women in a protest

\section{PATRIOTISM AND THE QUEST TO FIGHT FOR THE RIGHTS OF THE MASSES}

Failed expectations and negligence by the government and oil companies result in movements to emancipate the people of the region from the damaging effects of oil production activities on their land. Patriotic spirit in the film is represented by the roles of Ebiere, Dede, Tamuno and their fellow compatriots. However, expression of this patriotism varies based on orientations of the various activists. Ebiere believes in peaceful protest and is determined to go to whatever length in her fight for justice, thanks to the Western Oil scholarship which empowers her for the challenge. She, thus, takes it upon herself to mobilize the people along this line, and forms a vibrant non-violent movement that threatens even the authorities. She hinges her struggle on the quest to actualize the desired emancipation through non-violent process: 'violence never pays, there are better ways of sending a message across' is her favorite maxim. On how to make the struggle a reality, she explains: 'we can match down the streets of Lagos and Abuja, we can make the whole word hear our cries.'

This, however, is not as easy as Ebiere envisions, as the incorporation of youth makes it difficult to draw a distinction between the struggle which is intended to be a non-violent movement, and an armed struggle. Dede, leader of the youth, also sees it as a point of honor to fight for his land, and is determined to give his life for the course: 'at least I'll die fighting for something I believe in, fighting for my land...' he confides in Ebiele. This conviction he shares with his peers, although he does not believe in 
peaceful protest: 'I don't believe in doing this thing with protest, I want to fight, I want to make life unbearable for them...' Tamuno (Dede's cousin who has resigned from the Nigerian Police Force and joined the liberation movement, and would later become the leader after the demise of Dede) also shares in this vision, as he declares to Ebiere who is shocked to see him in the terrorist camp: 'do not be surprised, my people are my people, I would rather die on the right side...'

With this mindset, the youth anchor their struggle on violence, and give it expression through kidnapping of American oil workers and destruction of oil facilities. Ebiere, who is coopted to persuade the militants to lay down arms, finds the task really challenging, as negotiating a compromise between security operatives and the militants seems impossible, given the atmosphere of mutual distrust that prevails from both camps. Notwithstanding, she persuades the rebels to give in to the option of dialogue:

They have requested that you lay your arms ...before you consider the option [of violence], they have asked for dialogue, this is an opportunity for you to be free, a chance for you to return to your families...give peace a chance, give dialogue a chance...

At the end of the film, Ebiere, Dede and Tamuno prove their patriotism and commitment to the liberation movement beyond reasonable doubt. Dede offers to, and eventually dies with security operatives in the course of the struggle, his death which inspires Ebiere to be stronger and more determined as she declares during his interment:

They have killed our brothers, our sisters, our fathers, our mothers, even our children, but what they cannot kil is our spirit, for every time they put a knife through us we only get stronger, so this time, for Dede, we will be strong, for Dede...

In the same manner, Ebiere offers herself as a sacrificial lamb to save the rest of the community members who set fire on the three elders that liaise with the Western Oil company to exploit them. Although Ebiere warns them prior to the crime, the thought of having the whole community hanged convinces her to offer herself in other to exonerate the culprits in their numbers. Tamuno continues from this point, and extends the struggle to the United States, where he holds hostage, Tom Hudson to bargain for Ebiere's release. At the end of the film, therefore, it appears glaring that the fire of patriotism in residents of the Niger Delta region who have been deprived of the basic conditions of life by both the state 
and none-state actors is so high, and cannot be quenched by even the fierce resounding echo of military guns.

\section{CONCLUDING REMARKS}

The thematic discussion above dispels any doubt about the effectiveness of film in mirroring social reality towards attaining a better society. Black November has interrogated the Niger Delta question intensively. It has depicted the multifaceted nature of such issues that have continued to nurture, ignite and sustain constant upheavals and breakdown of law and order in the region. Scholarly literature has established these causes already, for instance, (Stiglitz, 2006) unmasks the mystery behind the politics of oil production in developing nations, where powerful nations of the West and multinational companies operate a sort of exploitative relationship that helps to keep the naturally endowed nations in a state of dependence. Indeed, Stiglitz and several other scholars decry this imperialistic relationship that amounts to a resource curse, or what they term the 'paradox of plenty' for developing nations. Black November is a screen representation of this thinking, kudos to the producer.

The film, however, can be criticized for one or two major weaknesses. First, it projects a victor-vanquish approach to the Niger Delta conflict, contrary to the position of (Nykon, 2011), who recommends three key strategies that producers of films must note towards achieving a peaceful society: (1) that there are viable alternatives to violent-contending methods of conflict resolution; (2) that positive outcomes for both parties can often be created; and (3) that all parties are worthy of being treated humanely. Black November falls short of the expectation of all these recommendations.

The second major weakness of the film is that it presents just the problem, without the solution. At the end of the film, both peaceful and violent struggles fail in providing solution to the Niger Delta conflict, a gap that leaves the audience to wonder which approach is the best for tackling the multifarious issues that cause conflict in the Niger Delta region. The film, thus, fails to demonstrate how the four principles of conflict management as given by (Jeong, 2010) - negotiation, mediation, facilitation and reconciliation work in practice. Notwithstanding this gap, the Entertainment-Education approach of (Singhal \& Rogers 1999) has been effectively deployed to present the realities of the conflict situation in the Niger Delta region. 


\section{References}

Abdussalam, I. K. (2014). Minority question and persistent instability in Nigeria: a product of imperfect colonial legacy, selfish politics and the poverty of history. In V. Egwemi, T. Wuam \& C.S. Orngu (Eds). Federalism, Politics and Minorities in Nigeria: Essays in Honour of Professor G.N. Hembe, (pp. 55-64). Lagos: Bahiti and Dalila Publishers.

Afinotan, L. A. \& Ojakorotu, V. (2009). The Niger Delta crisis: Issues, challenges and prospects. African Journal of Political Science and International Relations, 3(5), 191-198.

Anstey, M. (2008). Managing conflict: negotiating change. Cape Town: Juta.

Apuke, O. D. (2017). Exploring the issues in oil production in the Niger Delta region of Nigeria security challenges and suggested solutions. Arabian fournal of Business and Management Review (Oman Chapter), 6 (11), 59-83. Doi: 10.12816/0 039077

Chile, D. \& Targema, T. S. (2017). Film and good governance in Nigeria: an analysis of Praise Abraham's Tartor Wase. Paper presented at the 4th annual conference of the Association of Communication Scholars and Professionals of Nigeria, Green Desert Hotel, Kano, Nigeria, September, pp. 6-7.

Egbefo, D. O., Mohammed, A. B., Apara, S. A \& Ngarka, T. S. (2010). Peace studies and conflict resolution for Nigerian undergraduates. Jos: Star-Link Books.

Gallo, G. (2012). Conflict theory, complexity and systems approach. Systems Research and Behavioural Science, 30(5), 156-175. doi: 10.1002/sres.2132

Galtung, J. (1971). A structural theory of imperialism. fournal of Peace Research, 8(2), 81-117.

Jacobs, C. P. (n.d.). Film theory and approaches to criticism, or, what did a movie mean? Retrieved from

https://www.academia.edu/27698476/Film Theory and Approaches to Critici sm or What did that movie mean

Jeong, H. (2010). Conflict management and resolution: an introduction. New York: Routledge.

Katu-Ogundimu, N. N. (2013). Film review: an analysis of Funke Akindele's film Jenifa. Fournal of communication and media research, 5(2). 159-170.

Kurfi, M. Y. (2017). Film and conflict resolution in multi-cultural Nigeria. In U. Pate \& L. Oso (Eds.), Multiculturalism, Diversity and Reporting Conflict in Nigeria. (pp. 334-347). Ibadan: Evans Brothers (Nigeria Publishers) Limited.

Littlejohn, S. W. \& Foss, K. A. (2009). Encyclopaedia of communication theory. SAGE: New Delhi.

McPhail, T. L. (2009). Major theories following modernization. In T.L. McPhail (Ed.), Development Communication: Reframing the Role of the Media (pp. 21-48). West Sussex: Blackwell Publishing Ltd. 
Niger Delta States. Retrieved from https://en.m.wikipedia.org/wiki/Niger-Delta. Acessed, 4-12-2017

Nwabueze, C. (2014). Introduction to Mass Communication: Media Ecology in the Global Village. Owerri: Top Shelve Publishers.

Nwankwo, B. O. (2015). The politics of conflict over oil in the Niger Delta region of Nigeria: a review of the corporate social responsibility strategies of the oil companies. American Journal of Educational Research, 3(4), 383-392. Doi: 10.12691/ education-3-4-1.

Nykon, B. P. (2011). The feature film as a vehicle for disseminating principles of conflict resolution. Journal of Conflictology, 2(2), 18-30.

Oruonye, E.D. (2012). The socio-economic impact of land resource conflict in Taraba State: A case study of Kona - Minda crisis in Northern Taraba. International fournal of Environmental Sciences, 1(2), 46-49.

Owens-Ibie, N. \& Ademosu, I. (2017). Side by side: engaging Nigerian ethnic peculiarities in 'Phone Swap'. In U. Pate \& L. Oso (Eds.), Multiculturalism, Diversity and Reporting Conflict in Nigeria. (pp. 334-347). Ibadan: Evans Brothers (Nigeria Publishers) Limited.

Singhal, A. \& Rogers, E. (1999). Entertainment education: a communication strategy for social change. Mahwah, NJ: Lawrence Erlbaum Associates.

Stiglitz, J. E. (2006). Making globalization work. New York: W. W. Norton \& Company, Inc.

Suntai, D. I. \& Targema, T. S. (2017). Madagascar Escape 2 Africa and parents' career expectations for children: a thematic discourse. The Journal of African Theatre, Film and Media Discourse, 1(1), 78-88. Doi: 10.33886/kujat.v1i1.127

Tufte, T. (2002). Edutainment in HIV/AIDS prevention. building on the Soul City experience in South Africa. In J. Servaes, (Ed.), Approaches to Development Communication. Paris: UNESCO.

Yuguda, M. A \& Goni, I. (2013). Ethno-religious conflict in Taraba State and its implications on socioeconomic, political and educational development of youths. International fournal of Social Sciences and Humanities Reviews, 4(3), 149-155.

Список литературы

Abdussalam, I. K. (2014). Minority question and persistent instability in Nigeria: a product of imperfect colonial legacy, selfish politics and the poverty of history. In V. Egwemi, T. Wuam \& C.S. Orngu (Eds). Federalism, Politics and Minorities in Nigeria: Essays in Honour of Professor G.N. Hembe, (pp. 55-64). Lagos: Bahiti and Dalila Publishers.

Afinotan, L. A. \& Ojakorotu, V. (2009). The Niger Delta crisis: Issues, challenges and prospects. African Journal of Political Science and International Relations, 3(5), 191-198.

Anstey, M. (2008). Managing conflict: negotiating change. Cape Town: Juta. 
Apuke, O. D. (2017). Exploring the issues in oil production in the Niger Delta region of Nigeria security challenges and suggested solutions. Arabian fournal of Business and Management Review (Oman Chapter), 6 (11), 59-83. Doi: $10.12816 / 0039077$

Chile, D. \& Targema, T. S. (2017). Film and good governance in Nigeria: an analysis of Praise Abraham's Tartor Wase. Paper presented at the 4th annual conference of the Association of Communication Scholars and Professionals of Nigeria, Green Desert Hotel, Kano, Nigeria, September, pp. 6-7.

Egbefo, D. O., Mohammed, A. B., Apara, S. A \& Ngarka, T. S. (2010). Peace studies and conflict resolution for Nigerian undergraduates. Jos: Star-Link Books.

Gallo, G. (2012). Conflict theory, complexity and systems approach. Systems Research and Behavioural Science, 30(5), 156-175. doi: 10.1002/sres.2132

Galtung, J. (1971). A structural theory of imperialism. Fournal of Peace Research, 8(2), 81-117.

Jacobs, C. P. (n.d.). Film theory and approaches to criticism, or, what did a movie mean? Retrieved from https://www.academia.edu/27698476/Film Theory and Approaches to Critici sm or What did that movie mean

Jeong, H. (2010). Conflict management and resolution: an introduction. New York: Routledge.

Katu-Ogundimu, N. N. (2013). Film review: an analysis of Funke Akindele's film Jenifa. Fournal of communication and media research, 5(2). 159-170.

Kurfi, M. Y. (2017). Film and conflict resolution in multi-cultural Nigeria. In U. Pate \& L. Oso (Eds.), Multiculturalism, Diversity and Reporting Conflict in Nigeria. (pp. 334-347). Ibadan: Evans Brothers (Nigeria Publishers) Limited.

Littlejohn, S. W. \& Foss, K. A. (2009). Encyclopaedia of communication theory. SAGE: New Delhi.

McPhail, T. L. (2009). Major theories following modernization. In T.L. McPhail (Ed.), Development Communication: Reframing the Role of the Media (pp. 21-48). West Sussex: Blackwell Publishing Ltd.

Niger Delta States. Retrieved from https://en.m.wikipedia.org/wiki/Niger-Delta. Acessed, 4-12-2017

Nwabueze, C. (2014). Introduction to Mass Communication: Media Ecology in the Global Village. Owerri: Top Shelve Publishers.

Nwankwo, B. O. (2015). The politics of conflict over oil in the Niger Delta region of Nigeria: a review of the corporate social responsibility strategies of the oil companies. American fournal of Educational Research, 3(4), 383-392. Doi: 10.12691/ education-3-4-1.

Nykon, B. P. (2011). The feature film as a vehicle for disseminating principles of conflict resolution. Journal of Conflictology, 2(2), 18-30. 
Oruonye, E.D. (2012). The socio-economic impact of land resource conflict in Taraba State: A case study of Kona - Minda crisis in Northern Taraba. International Fournal of Environmental Sciences, 1(2), 46-49.

Owens-Ibie, N. \& Ademosu, I. (2017). Side by side: engaging Nigerian ethnic peculiarities in 'Phone Swap'. In U. Pate \& L. Oso (Eds.), Multiculturalism, Diversity and Reporting Conflict in Nigeria. (pp. 334-347). Ibadan: Evans Brothers (Nigeria Publishers) Limited.

Singhal, A. \& Rogers, E. (1999). Entertainment education: a communication strategy for social change. Mahwah, NJ: Lawrence Erlbaum Associates.

Stiglitz, J. E. (2006). Making globalization work. New York: W. W. Norton \& Company, Inc.

Suntai, D. I. \& Targema, T. S. (2017). Madagascar Escape 2 Africa and parents' career expectations for children: a thematic discourse. The fournal of African Theatre, Film and Media Discourse, 1(1), 78-88. Doi: 10.33886/kujat.v1i1.127

Tufte, T. (2002). Edutainment in HIV/AIDS prevention. building on the Soul City experience in South Africa. In J. Servaes, (Ed.), Approaches to Development Communication. Paris: UNESCO.

Yuguda, M. A \& Goni, I. (2013). Ethno-religious conflict in Taraba State and its implications on socioeconomic, political and educational development of youths. International fournal of Social Sciences and Humanities Reviews, 4(3), 149-155. 